Огляди літератури, оригінальні дослідження, погляд на проблему, випадок з практики, короткі повідомлення УДК 616.37-002-07-085:616.36-002

DOI 10.11603/1811-2471.2019.v0.i2.10371

\title{
КЛІНІЧНІ АСПЕКТИ ХРОНІЧНОГО ПАНКРЕАТИТУ В ПОЄДНАННІ IЗ ВІРУСНИМ ГЕПАТИТОМ С
}

\section{Тернопільський національний медичний університет імені Я горбачевського Моз Украйнайген \\ Тернопільський національний медичний університет імені І. Я. Горбачевського мОз України}

РЕЗЮМЕ. У статті проаналізовані особливості поєднаного перебігу хронічного панкреатиту із вірусним гепатитом С. Проведені дослідження показали негативний вплив супутнього вірусного гепатиту С на перебіг хронічного панкреатиту, що виражався більш значно вираженими клінічними патологічними ознаками, порівняно із групою ізольованого хронічного панкреатиту.

В останні роки збільшилась увага до інфекційного чинника, вплив якого може призвести до розвитку запального процесу в підшлунковій залозі. Значне поширення вірусного гепатиту С серед населення, різноманітність його позапечінкових проявів обумовлюють актуальність проблеми. Недостатність розробки питань первинної та вторинної профілактики хронічного панкреатиту мотивує до глибшого вивчення механізму його розвитку на тлі вірусного гепатиту С.

Мета - вивчити клінічний перебіг хронічного панкреатиту у хворих із супутнім вірусним гепатитом C.

Матеріал і методи. Обстежено 57 хворих на хронічний панкреатит із супутнім вірусним гепатитом С. Групу порівняння склали 20 осі6, хворих на хронічний панкреатит. Для встановлення клінічного діагнозу хронічного панкреатиту та вірусного гепатиту С усі хворі були обстежені згідно із протоколами МОЗ України (накази № 638 МОЗ України від 10.09.2014р. та № 729 МОЗ України від 18.07.2016р.). Діагноз хронічного панкреатиту та вірусного гепатиту С верифікували на підставі даних анамнезу захворювання, клінічних проявів і результатів лабораторноінструментальних досліджень. Загальноклінічні й біохімічні обстеження проводили хворим на хронічний панкреатит у фазі загострення та нестійкої ремісії, хворим на вірусний гепатит С - у фазі стійкої ремісії.

Результати. У клінічному перебігу хронічного панкреатиту із супутнім вірусним гепатитом С провідне місце займали больовий, диспепсичний синдроми та порушення випорожнення. Вони були більш значно виражені, ніж у групі порівняння (вірогідна відмінність стосовно показників групи ізольованого хронічного панкреатиту $(p<0,05)$ ). У хворих на хронічний панкреатит із супутнім вірусним гепатитом С виявили анемію легкого ступеня, зниження рівня альбуміну в крові, гіпербілірубінемію, гіперхолестеринемію, підвищення рівнів АлТ та АСТ, амілази крові та діастази сечі $(p<0,05)$. У хворих на хронічний панкреатит із супутнім вірусним гепатитом С сумарний рівень копрограми у балах склав $(5,20 \pm 0,82)$, а в хворих на хронічний панкреатит - $(3,10 \pm 0,32)$; було виявлено значно гірші рівні показників, більш виражений запальний синдром і дисбактеріоз. У двох досліджуваних групах переважала стеаторея II типу. Глибина структурних змін у підшлунковій залозі за даними УзД у групі хворих на хронічний панкреатит із супутнім вірусним гепатитом С становила $(2,56 \pm 1,10)$ балів, що відповідає процесу середнього ступеня тяжкості, у групі ізольованого хронічного панкреатиту - $(1,90 \pm 0,60)$ балів.

Висновки. За оцінкою даних дослідження встановлено негативний вплив супутнього вірусного гепатиту С на клінічний перебіг хронічного панкреатиту.

КЛючОВІ СЛОВА: хронічний панкреатит; вірусний гепатит С; копрограма; структурний стан підшлункової залози; клінічний перебіг.

Вступ. Проблема хронічного панкреатиту (ХП) у сучасній світовій медицині $\epsilon$ актуальною. Значно зросла поширеність патології травної системи за останні роки і в Україні. Так, поширеність хронічного гепатиту (ХГ) з 2008 по 2012 р. збільшилась у 2,2 раза, захворюваність на патологію підшлункової залози (П3) - у 3,2 раза. За даними Центру медичної статистики МОЗ України, за 2006-2013 рр. показники госпіталізації при хронічному перебігу ХП зросли на 30,2 \%. При цьому у переважної частини пацієнтів гастроентерологічних клінік діагностують декілька захворювань, і одним із найчастіших захворювань, які перебігають у поєднанні із ХГ і цирозом печінки, $\in$ ХП [1]. При поєднаному ураженні печінки та ПЗ прогноз для одужання сприятливий рідко, оскільки тактика лікування особливо ускладнюється [2]. Не- сприятливі умови, що склались в останні десятиліття, а саме епідемія вірусних гепатитів, зростання споживання алкоголю, поширення ожиріння та метаболічного синдрому, а відтак і неалкогольної жирової хвороби печінки, обумовлюють подальше зростання кількості пацієнтів із термінальними захворюваннями печінки, пік яких, за даними епідеміологічного аналізу, припадає на 2010-2020 роки [3].

За останні роки збільшилась увага до інфекційного чинника, який може спричинити розвиток запального процесу в ПЗ [1]. Гепатити, пов'язані 3 інфекцією вірусного гепатиту С (ВГС), $\epsilon$ прогресуючою хворобою, яка може призвести до хронічного активного гепатиту, цирозу та гепатоцелюлярної карциноми. Хронічний гепатит С (ХГС) тривалий час перебігає за типом персистентного 3 
Огляди літератури, оригінальні дослідження, погляд на проблему, випадок з практики, короткі повідомлення мінімально вираженими клінічними і біохімічними ознаками активності процесу, що є причиною пізньої діагностики [4]. Морфологічні зміни у печінці при ХГС нерідко не відповідають клініко-біохімічним, і навіть цироз печінки може перебігати безсимптомно. Найчастіше від моменту зараження до появи перших ознак інфекції проходить тривалий латентний період. Встановлено низку факторів, які негативно впливають на природний перебіг ХГС: вік більше 40 років до моменту інфікування, чоловіча стать, раса (не європеоїдна), зловживання алкоголем, ожиріння, порушення обміну заліза, метаболічний синдром [5].

За оцінками експертів, близько 160 млн осіб, тобто 2,35 \% населення світу, хронічно інфіковані ВГС. Крім того, печінкова недостатність, як наслідок інфікування ВГС, є однією з найпоширеніших причин трансплантації печінки [5]. Позапечінкові прояви хронічної інфекції ВГС переважно є імунологічними; однак вірус може мати пряму цитопатичну дію, тому що може інфікувати багато інших тканин, крім печінки [2]. У багатьох пацієнтів із хронічним ВГС розвивається цукровий діабет 2 типу. Ця поширеність набагато вища, ніж у загальній популяції та у пацієнтів з іншими хронічними захворюваннями печінки, такими як вірус гепатиту $\mathrm{B}$, алкогольне захворювання печінки та первинний біліарний цироз [2]. Можлива біологічна причина зв'язку між ВГС і раком ПЗ. Відомо, що пацієнти з діагнозом гострого гепатиту С хворіють також на гострий панкреатит. Крім того, рівень ферментів ПЗ у сироватці збільшується 3 прогресуванням захворювання печінки у пацієнтів з діагнозом вірусного гепатиту [6]. Значне поширення HCV-інфекції серед населення, висока частота хронізації захворювання з формуванням цирозу печінки та гепатоцелюлярної карциноми, а також різноманіття позапечінкових проявів обумовлюють актуальність проблеми ХГС [7]. Водночас недостатність розробки питань первинної та вторинної профілактики ХП мотивує до глибшого вивчення механізму його розвитку на тлі ХГС, а також до розробки нових підходів до профілактики, лікування та реабілітації.

Мета - вивчити особливості клінічного перебігу хронічного панкреатиту у хворих із супутнім вірусним гепатитом C.

Матеріал і методи дослідження. Обстежено 57 хворих на ХП із супутнім ВГС (І група), які перебували на диспансерному обліку в центрі первинної медико-санітарної допомоги м. Тернопіль та в гастроентерологічному відділені НКР «ТМКЛ № 2». Групу порівняння склали 20 хворих на ХП (II група). Джерелом інформації слугували «Медичні карти амбулаторного хворого» (ф. 025/о) і «Медичні карти стаціонарного хворого» (ф. 003/о)

обстежених пацієнтів. Для встановлення клінічного діагнозу ХП та ВГС усі хворі були обстежені згідно із протоколами (накази МОЗ України № 638 від 10.09.2014 р. та № 729 від 18.07.2016 р.). Середній вік усіх хворих становив $(53,5 \pm 22,5)$ років. Переважали пацієнти працездатного віку. Діагноз ХП та ВГС верифікували на підставі даних анамнезу захворювання, клінічних проявів і результатів лабораторно-інструментальних досліджень. Загальноклінічні і біохімічні обстеження проводили хворим на ХП у фазі загострення та нестійкої ремісії, хворим на ВГС - у фазі стійкої ремісії (рівень АлТ нормальний). Було проаналізовано результати копрологічного дослідження у двох групах. Кожну патологічну ознаку копрограми оцінювали в один 1 бал, вважаючи за норму добову кількість калу - 120-200 г (форма - ковбасоподібна, консистенція - однорідна, колір - коричневий, неперетравлені залишки їжі - нема, слиз - нема, кров нема, гній - нема, нормальна йодофільна мікрофлора - невелике число, паразити і найпростіші нема, $\mathrm{pH}-6,0-8,0$, м'язові волокна - поодинокі, нейтральний жир - нема, жирні кислоти - поодинокі, крохмаль і мила - незначна кількість, перетравлена клітковина - поодинока, оксалати нема, стеркобілін - у невеликій кількості, білірубін - нема). Для інтерпретації результатів УзД ПЗ у балах використовували критерії візуалізації за Марсельсько-Кембріджською класифікацією ХП. Отримані дані були статистично опрацьовані за допомогою програми «Microsoft Excel». Обчислювали середні арифметичні величини (M) із середніми квадратичними відхиленнями (m). Для перевірки статистичних гіпотез застосовували параметричні та непараметричні методи. При параметричному розподілі використовували t-критерій Стьюдента, при непараметричному - U-критерій Манна-Уїтні. При перевірці статистичних гіпотез нульову гіпотезу відкидали при рівні статистичної значимості $p<0,05$.

Результати й обговорення. У клінічному перебігу ХП із супутнім ВГС провідне місце займали больовий, диспепсичний синдроми і порушення випорожнення. Вони були більш значимо виражені, ніж у групі хворих на ізольований ХП (табл. 1).

У хворих на ХП із супутнім ВГС виявили анемію легкого ступеня, зниження рівня альбуміну у крові, гіпербілірубінемію, гіперхолестеринемію, підвищення рівнів ферментів АлТ та АСТ, підвищення рівнів амілази крові та діастази сечі (табл. 2).

Зміни показників крові свідчать про наявність порушень різних ланок обміну речовин у хворих на ХП із супутнім ВГС, які були достовірно більш значимими, ніж у II групі, що свідчить про 
Огляди літератури, оригінальні дослідження, погляд на проблему, випадок з практики, короткі повідомлення Таблиця 1. Основні гастроентерологічні синдроми у групах хворих на хронічний панкреатит залежно від наявності супутнього вірусного гепатиту C (M士m)

\begin{tabular}{|l|c|c|}
\hline \multicolumn{1}{|c|}{ Клінічний синдром і симптом } & $\begin{array}{c}\text { I група } \\
\text { (хворі на ХП із супутнім ВГС) } \\
\mathrm{n=57}\end{array}$ & $\begin{array}{c}\text { II група } \\
\text { (хворі на ХП) } \\
\text { n=20 }\end{array}$ \\
\hline Больовий синдром, \% & $100,0^{*}$ & 80,0 \\
\hline Диспепсичний синдром, \% & $87,5^{*}$ & 70,0 \\
\hline Порушення випорожнення, \% & $89,4^{*}$ & 65,0 \\
\hline Запор, \% & $33,3^{*}$ & 25,0 \\
\hline Пронос, \% & $26,8^{*}$ & 15,0 \\
\hline Чергування запорів і проносів, \% & $45,6^{*}$ & 45,0 \\
\hline
\end{tabular}

Примітка. * - вірогідна відмінність показників I групи стосовно показників II групи ( $<<0,05)$.

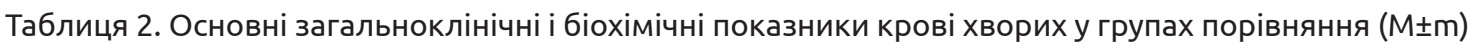

\begin{tabular}{|c|c|c|}
\hline Лабораторний показник & $\begin{array}{c}\text { I група } \\
\text { (хворі ХП із супутнім ВГС) } \\
\text { n=57 }\end{array}$ & $\begin{array}{c}\text { II група } \\
\text { (хворі XП) } \\
\mathrm{n}=20 \\
\end{array}$ \\
\hline Еритроцити, ×1012 $\pi^{-1}$ ж. & $4,02 \pm 0,33 *$ & $4,48 \pm 0,11$ \\
\hline Гемоглобін, г/л ж. & $117,0 \pm 10,04^{*}$ & $132,0 \pm 9,48$ \\
\hline Еритроцити, $\times 10^{12} \pi^{-1} 4$. & $4,4 \pm 0,2^{*}$ & $4,58 \pm 0,13$ \\
\hline Гемоглобін, г/л ч. & $140,0 \pm 7,6^{*}$ & $154,0 \pm 9,43$ \\
\hline Лейкоцити, ×109/л & $5,34 \pm 1,13^{*}$ & $5,27 \pm 1,06$ \\
\hline ШОЕ, мм/год & $9,0 \pm 5,59 *$ & $8,0 \pm 5,47$ \\
\hline Загальний білірубін, мкмоль/л & $29,64 \pm 11,28 *$ & $15,83 \pm 3,76$ \\
\hline Загальний білок, г/л & $58,02 \pm 6,67 *$ & $82,6 \pm 3,54$ \\
\hline Загальний холестерин, ммоль/л & $5,52 \pm 0,83^{*}$ & $4,4 \pm 0,56$ \\
\hline АЛТ, ммоль/л & $1,36 \pm 0,51$ * & $0,47 \pm 0,14$ \\
\hline АСТ, ммоль/л & $0,66 \pm 0,14^{*}$ & $0,26 \pm 0,11$ \\
\hline Амілаза крові, мг/(год×мл) & $38,97 \pm 9,08 *$ & $26,73 \pm 3,83$ \\
\hline Діастаза сечі, мг/(год×мл) & $168,6 \pm 97,34^{*}$ & $98,96 \pm 58,12$ \\
\hline
\end{tabular}

Примітка. * - вірогідна відмінність показників I групи стосовно показників II групи ( $<<0,05)$.

ускладнювальну роль супутнього ВГС на лабораторні параметри хворих на ХП.

Наступним етапом стала порівняльна бальна оцінка сумарного бала копрограми і структурних змін ПЗ за даними УзД. У хворих на ХП із супутнім ВГС сумарний рівень копрограми склав $(5,20 \pm 0,82)$ балів, а в хворих на ХП- $(3,10 \pm 0,32)$ балів, що довело глибший рівень копрологічних змін при коморбідності ХП і ВГС (рис. 1). У обох досліджуваних групах переважала стеаторея II типу.

При аналізі копрограм хворих на ХП із супутнім ВГС у порівнянні із групою ізольованого ХП було виявлено більш значно виражені патологічні зміни, що довело негативний вплив ВГС на клінічний перебіг ХП. Це констатовано на основі виявлення значно гірших рівнів показників, більш вираженого запального синдрому і ознак дисбіо- зу, що й засвідчило вищий рівень порушення зовнішньосекреторної функції ПЗ при коморбідності ХП і ВГС.

Аналіз показників УЗД ПЗ у балах у хворих груп дослідження показав, що глибина структурних змін ПЗ у групі хворих на ХП із супутнім ВГС становила $(4,56 \pm 0,55)$ балів, що відповідало процесу середнього ступеня тяжкості. У групі паці$\epsilon$ нтів з ХП без ВГС ступінь ураження склав $(1,90 \pm 0,30)$ балів (рис. 2).

Порівняння цих параметрів $(p<0,05)$ дозволило констатувати достовірно більш глибокі структурні зміни у ПЗ (за даними УЗД) хворих із супутнім ВГС.

Вищенаведене довело ускладнювальну роль наявності ВГС у фазі ремісії на клінічний перебіг ХП і лабораторно-інструментальні параметри у пацієнтів із таким коморбідним поєднанням. 
Огляди літератури, оригінальні дослідження, погляд на проблему, випадок з практики, короткі повідомлення

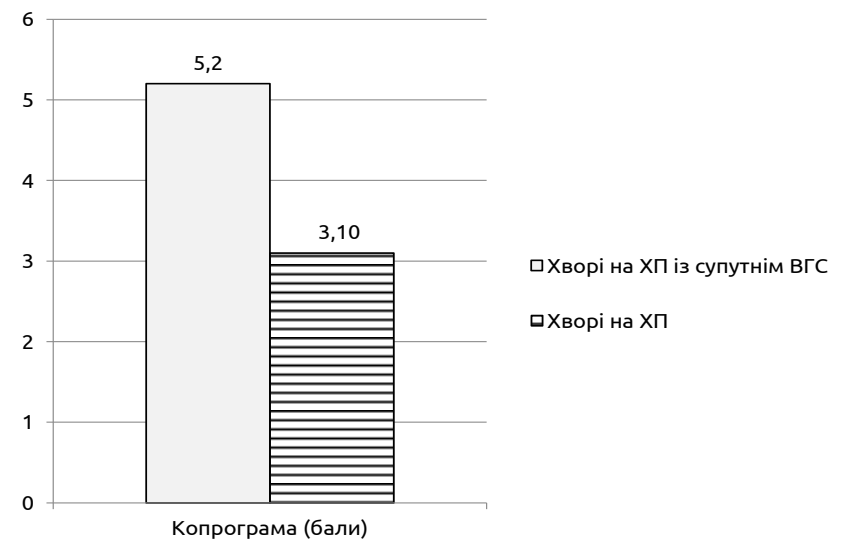

Примітка. Вірогідна відмінність показників групи дослідження стосовно групи порівняння $(p<0,05)$.

Рис. 1. Сумарний рівень копрограми в балах у групах порівняння.

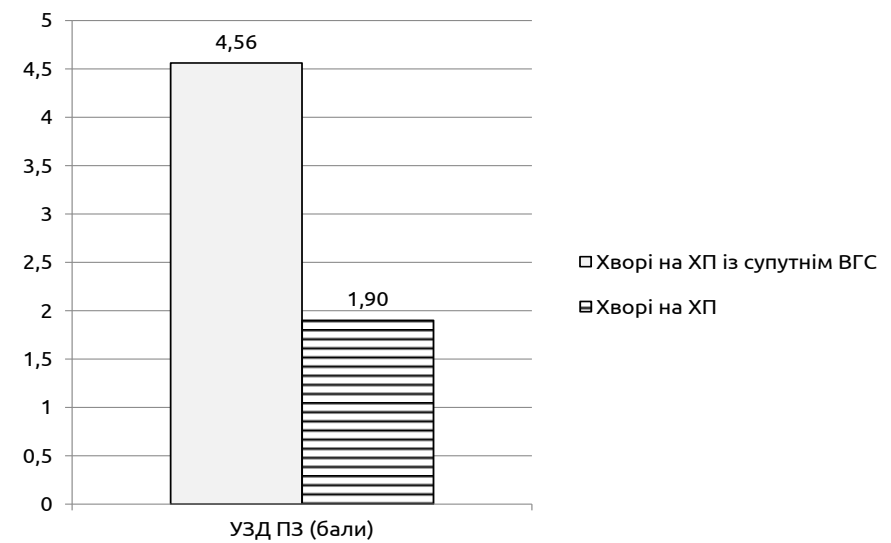

Примітка. Вірогідна відмінність показників групи дослідження стосовно групи порівняння $(p<0,05)$.

Рис. 2. Сумарний показник УзД ПЗ в балах у групах порівняння.

Висновок. Порівняльний аналіз клініко-лабораторно-інструментальних ознак хворих на ХП залежно від наявності ВГС виявив наступні ознаки такої коморбідності: більше вираження больового і диспепсичного синдромів, поглиблення лабораторних проявів у вигляді анемії легкого ступеня, зниження рівня альбуміну в крові, гіпербілірубінемії, гіперхолестеринемії, підвищення рівня ферментів АЛТ та АСТ, підвищення рівнів амілази крові та діастази сечі, збільшення сумарного баль-

\section{ЛІТЕРАТУРА}

1. Пасиешвили Л. М. Роль вирусной инфекции в поражении поджелудочной железы у больных ишемической болезнью сердца / Л. М. Пасиешвили, А. А. Заздравнов // Врачебная практика. - 2001. - № 4. - С. 43-45.

2. Губергриц Н. Б. Современные возможности лечения сочетания хронического гепатита и хронического панкреатита токсической этиологии / Н. Б. Губергриц // Участковый врач. - 2015. - № 6. - С. 23-25. ного рівня копрограми (ознаки більш вираженого запального синдрому і дисбіозу товстої кишки), що й засвідчило вищий рівень порушення зовнішньосекреторної функції ПЗ, а також збільшення сумарного бала УЗ-змін підшлункової залози до рівня середнього ступеня тяжкості за МарсельськоКембріджською класифікацією.

У перспективі планується поглибити вивчення клініко-патогенетичних особливостей перебігу ХП у поєднанні із ВГС.

3. Инфекции и их место среди других причин возникновения панкреатита / Ю. И. Решетилов, А. И. Токаренко, С. Н. Дмитриева [и др.] // Сучасна гастроентерологія. - 2012. - № 2 (8). - С. 24-29.

4. Гаврилюк А. О. Наслідки хронічних вірусних гепатитів B, C та B+C / A. О. Гаврилюк // Клінічна та експериментальна патологія. - 2015. - T. XIV, № 4, С. 203-208. 
Огляди літератури, оригінальні дослідження, погляд на проблему, випадок з практики, короткі повідомлення

5. Лапасов С. Х. Диагностика, лечение и профилактика хронического гепатита С в условиях первичного звена медицинской помощи (обзор литературы) / С. Х. Лапасов // Здобутки клінічної і експериментальної медицини. - 2017. - № 2 (30). - С. 13-21.

6. Risk of hepatobiliary and pancreatic cancers following hepatitis C virus infection / H. El-Serag, E. A. Engels,
O. Landgren [et al.] // Hepatology. - 2009. - No. 49 (1). P. 116-123. DOI: [10.1002/hep.22606].

7. Взаємозв'язки імунологічних та клініко-морфологічних показників у хворих на хронічний гепатит С залежно від наявності змішаної кріоглобулінемії/ О. П. Машко, О. В. Рябоконь, Т. Є. Онищенко, О. О Фурик // Актуальная инфектология. - 2016. - № 2 (11). - С. 171-175.

\section{REFERENCES}

1. Pasieshvili, L.M., \& Zazdravnov, A.A. (2001). Rol virusnoy infektsii v porazhenii podzheludochnoy zhelezy u bolnykh ishemicheskoy boleznyu serdtsa [The role of viral infection in pancreatic lesions in patients with coronary heart disease]. Vrachebnaya praktika - Medical Practice, 4, 43-45 [in Russian].

2. Gubergrits, N.B. (2015). Sovremennyye vozmozhnosti lecheniya sochetaniya khronicheskogo gepatita i khronicheskogo pankreatita toksicheskoy etiologii [Modern possibilities of treatment of a combination of chronic hepatitis and chronic pancreatitis of toxic etiology]. Uchastkovyy vrach - District Doctor, 6, 23-25 [in Russian].

3. Reshetilov, Yu.I., Tokarenko, A.I., Dmitrieva, S.N., Kuznetsova, L.F., Surmilo, N.N., Protsenko, N.N., Klavdieva, E.Yu., \& Kremzer, A.A. (2002). Infektsii i ikh mesto sredi drugikh prichin vozniknoveniya pankreatita [Infections and their place among other causes of pancreatitis]. Suchasna hastroenterolohiia-Modern Gastroenterology, 2 (8), 24-29 [in Russian].

4. Havryliuk, A.O. (2015). Naslidky khronichnykh virusnykh hepatytiv $B, C$ ta $B+C$ [Consequences of chronic viral hepatitis $\mathrm{B}, \mathrm{C}$ and $\mathrm{B}+\mathrm{C}]$. Klinichna ta eksperymentalna pa-

tolohiia - Clinical and Experimental Pathology, 4, 203-208 [in Ukrainian].

5. Lapasov, S.Kh. (2017). Diagnostika, lecheniye i profilaktika khronicheskogo gepatita C v usloviyakh pervichnogo zvena meditsinskoy pomoshchi (obzor literatury) [Diagnosis, treatment and prevention of chronic hepatitis $\mathrm{C}$ in primary care (literature review)]. Zdobutky klinichnoi $i$ eksperymentalnoi medytsyny - Achievements of Clinical and Experimental Medicine, 2 (30), 13-21 [in Russian].

6. El-Serag H., Engels E. A., Landgren O., Chiao E., Henderson L., Amaratunge H. C., Giordano T.P. (2009). Risk of hepatobiliary and pancreatic cancers following hepatitis Cvirusinfection. Hepatology, 49 (1), 116-123.DOI:[10.1002/ hep.22606].

7. Mashko, O.P. (2016). Vzaiemozviazky imunolohichnykh ta kliniko-morfolohichnykh pokaznykiv u khvorykh na khronichnyi hepatyt $C$ zalezhno vid naiavnosti zmishanoi kriohlobulinemii [Interconnection of immunological and clinical morphological parameters in patients with chronic hepatitis $C$ depending on the presence of mixed cryoglobulinemia]. Aktualnaya infektologiya - Actual Infectology, 2 (11), 171-175 [in Ukrainian].

\section{КЛИНИЧЕСКИЕ АСПЕКТЫ ХРОНИЧЕСКОГО ПАНКРЕАТИТА В СОЧЕТАНИИ С ВИРУСНЫМ ГЕПАТИТОМ С}

\section{сл. С. Бабинец, Е. Р. Шайген \\ Тернопольский национальный медицинский университет имени И. Я. Горбачевского МОз Украины}

PЕзЮМЕ. В статье проанализированы особенности сочетанного течения хронического панкреатита с вирусным гепатитом С. Проведенные исследования показали негативное влияние сопутствующего вирусного гепатита С на течение хронического панкреатита, которое выражалось более значительно выраженными клиническими патологическими признаками, по сравнению с группой изолированного хронического панкреатита.

В последние годы увеличилось внимание к инфекционному фактору, влияние которого может привести к развитию воспалительного процесса в поджелудочной железе. Широкое распространение вирусного гепатита С среди населения, разнообразие его внепеченочных проявлений обусловливают актуальность проблемы. Недостаточность разработки вопросов первичной и вторичной профилактики хронического панкреатита мотивирует к более глубокому изучению механизма его развития на фоне вирусного гепатита С.

Цель - изучить клиническое течение хронического панкреатита у больных с сопутствующим вирусным гепатитом С.

Материал и методы. Обследовано 57 больных хроническим панкреатитом с сопутствующим вирусным гепатитом С. Группу сравнения составили 20 человек, больных хроническим панкреатитом. Для установления клинического диагноза хронического панкреатита и вирусного гепатита С все больные были обследованы согласно протоколам МОЗ Украины (приказы № 638 МЗ Украины от 10.09.2014 г. и № 729 МЗ Украины от 18.07.2016 г.). Диагноз хронического панкреатита и вирусного гепатита С верифицировали на основании данных анамнеза заболе- 
Огляди літератури, оригінальні дослідження, погляд на проблему, випадок з практики, короткі повідомлення вания, клинических проявлений и результатов лабораторно-инструментальных исследований. Общеклинические и биохимические обследования проводили больным хроническим панкреатитом в фазе обострения и нестойкой ремиссии, больным вирусным гепатитом С - в фазе стойкой ремиссии.

Результаты. В клиническом течении хронического панкреатита с сопутствующим вирусным гепатитом С ведущее место занимали болевой, диспепсический синдромы и нарушения испражнения. Они были более значительно выражены, чем в группе сравнения (достоверное отличие относительно показателей группы изолированного хронического панкреатита $(p<0,05))$. Обнаружили анемию легкой степени, снижение уровня альбумина в крови, гипербилирубинемию, гиперхолестеринемию, повышение уровня АЛТ и АСТ, амилазы крови и диастазы мочи $(p<0,05)$. У больных хроническим панкреатитом с сопутствующим вирусным гепатитом С суммарный уровень копрограммы в баллах составил $(5,20 \pm 0,82)$, а у больных хроническим панкреатитом - $(3,10 \pm 0,32)$; 6ыло обнаружено значительно худшие уровни показателей, более выраженный воспалительный синдром и дисбактериоз. В обеих исследуемых группах преобладала стеаторея II типа. Глубина структурных изменений в поджелудочной железе по данным УЗИ в группе больных хроническим панкреатитом с сопутствующим вирусным гепатитом С составила $(2,56 \pm 1,10)$ баллов, что соответствует процессу средней степени тяжести, в группе изолированного хронического панкреатита - $(1,90 \pm 0,60)$ баллов.

Выводы. Вследствие оценки данных исследования было установлено негативное влияние сопутствующего вирусного гепатита С на клиническое течение хронического панкреатита.

КЛЮЧЕВЫЕ СЛОВА: хронический панкреатит; вирусный гепатит С; копрограмма; структурное состояние поджелудочной железы; клиническое течение.

\section{CLINICAL ASPECTS OF CHRONIC PANCREATITIS IN COMBINATION WITH VIRAL HEPATITIS C @L. S. Babinets, O. R. Shaygen \\ I. Horbachevsky Ternopil National Medical University}

SUMMARY. The article analyzes the peculiarities of the combined course of chronic pancreatitis with viral hepatitis $C$. Studies conducted showed the negative effects of concomitant viral hepatitis $C$ on the course of chronic pancreatitis, which was expressed more marked clinical pathological features compared with the group of isolated chronic pancreatitis.

In recent years, attention has increased to the infectious agent, whose influence may lead to the development of inflammation in the pancreas. Significant spread of viral hepatitis $\mathrm{C}$ among the population, the diversity of its extrahepatic manifestations condition the relevance of the problem. The inadequacy of the development of issues of primary and secondary prevention of chronic pancreatitis motivates a deeper study of the mechanism of its development against the background of viral hepatitis $C$.

The aim of the study - the clinical course of chronic pancreatitis in patients with concomitant viral hepatitis C.

Materials and Methods. A total of 57 patients with chronic pancreatitis with concomitant viral hepatitis $C$ were examined. The comparison group consisted of 20 persons with chronic pancreatitis. In order to establish a clinical diagnosis of chronic pancreatitis and viral hepatitis C, all patients were examined in accordance with the protocols adopted for patients on orders No. 638 of the Ministry of Health of Ukraine dated September 10, 2014 and No. 729 of the Ministry of Health of Ukraine dated July 18, 2016. Diagnosis of chronic pancreatitis and viral hepatitis. They were verified on the basis of the medical history, clinical manifestations and research results. General clinical and biochemical examinations were performed in patients with chronic pancreatitis in the phase of exacerbation and unstable remission, patients with viral hepatitis $\mathrm{C}$ - in the phase of stable remission.

Results. In the clinical course of chronic pancreatitis with concomitant viral hepatitis C, pain, dyspeptic syndromes, and defecation were taken the leading place. They were more pronounced than in the comparison group (a significant difference in the parameters of the group of isolated chronic pancreatitis $(p<0.05)$ ). Patients with chronic pancreatitis with concomitant viral hepatitis $C$ had mild anemia, decreased blood albumin, hyperbilirubinemia, hypercholesterolemia, elevations in ALT and AST, blood amylase and urinary diastase $(p<0.05)$. In patients with chronic pancreatitis with concomitant viral hepatitis $C$, the total level of coprograms in points was $(5.20 \pm 0.82)$, and in patients with chronic pancreatitis (3.10 \pm 0.32 ); Significantly lower levels of indicators were detected, more pronounced inflammatory syndrome and dysbiosis. In the two study groups, steatorrhea of type II prevailed. The depth of structural changes in the pancreas according to the data of ultrasound in the group of patients with chronic pancreatitis with concomitant viral hepatitis $C$ was $(2.56 \pm 1.10)$ points, which corresponds to the process of moderate severity, in the group of isolated chronic pancreatitis - $(1.90 \pm 0.60)$ points.

Conclusions. According to the study data, the negative effect of the concomitant viral hepatitis $C$ on the clinical course of chronic pancreatitis was established.

KEY WORDS: chronic pancreatitis; viral hepatitis C; coprogram; structural state of the pancreas; clinical course. 